\title{
Evaluation of Spirulina platensis extract as natural antivirus against foot and mouth disease virus strains (A, 0 , SAT2)
}

Hind M. Daoud ${ }^{1}$ and Eman M. Soliman ${ }^{2}$

\author{
1. Department of Foot and Mouth, Veterinary Serum and Vaccine Research Institute, Abbassia, Cairo, Egypt; \\ 2. Central Laboratory for Evaluation of Veterinary Biologics, Abbassia, Cairo, Egypt. \\ Corresponding author: Eman M. Soliman, e-mail: emansoliman1880@gmail.com, HMD: hind.doud@hotmail.com \\ Received: 22-05-2015, Revised: 05-09-2015, Accepted: 15-09-2015, Published: 31-10-2015
}

doi: 10.14202/vetworld.2015.1260-1265 How to cite this article: Daoud HM, Soliman EM (2015) Evaluation of Spirulina platensis extract as natural antivius against foot and mouth disease virus strains (A, O, SAT2), Veterinary World 8(10): 1260-1265.

\begin{abstract}
Aim: This work was aimed to document the antiviral activates of Spirulina platensis extract against foot and mouth disease virus (FMDV) different types to evaluate its replication in Baby Hamster Kidney (BHK) cell culture and in baby mice.

Materials and Methods: Cytotoxicity assay studied for S. platensis extract on BHK cells to determine the non-toxic dose. The non-toxic dose of Spirulina extract was mixed with each type of FMDV (A, O, SAT2). Then 10-fold dilutions from each mixture were done. FMDV titer for each type of treated FMDV was calculated to evaluate the antiviral activity of the Spirulina extract against FMDV. Furthermore, old baby Swiss mice were inoculated with $0.1 \mathrm{ml}$ intraperitonially from the mixture of FMDV different types and different concentration of Spirulina extracts. After $48 \mathrm{~h}$ post inoculation, all the baby mice examined to evaluate the antiviral action of Spirulina extract.
\end{abstract}

Results: The result showed that the non-toxic doses of $S$. platensis (50 ug/ml) revealed 35.7\%, 28.5\%, and 31\% reductions in FMDV titers Type O, A, and SAT2 on BHK cells, respectively. The same non-toxic dose gave $50 \%$ of the inhibitory concentration in baby mice without cytotoxic effect.

Conclusion: This study confirmed the biological activity of the ethanol extract of S. platensis against FMDV Types O, A, and SAT2. From the results, S. platensis could be useful as antiviral lead to limitation of infection among animals during outbreaks but further studies need to evaluate the $S$. platensis on experimental or natural infected farm animals to establish the effective dose side affected period of treatment of $S$. platensis.

Keywords: antiviral, foot and mouth disease virus, Spirulina platensis.

\section{Introduction}

Pharmaceutical drug discoveries, for past 140 years depended largely on the process of empirical screening of a large number of pure compounds. Algal organisms are a rich source of structurally novel and biologically active metabolites. Secondary or primary metabolites produced by these organisms may be potential bioactive compounds of interest in the pharmaceutical industry [1-3].

$S$. platensis is blue-green algae belong to the family of Oscillatoriaceae in the shape of a spiral coil, living both in the sea and freshwater $[4,5]$. It contains various essential nutrients. It contains one of the highest protein content of $70 \%$ where 18 , out of 22 , essential amino acids are available. It is popular vegetarian source of complete protein [6]. Genus S. platensis which have applications in healthy foods, animal feed, therapeutics, and diagnostics [7-10]. Spirulina has been used as food and nutritional supplements since a long time. It is generally a rich source of protein, vitamins, essential amino acids, minerals, essential fatty acids such as ã-linolenic acid and sulfolipid [11].

Several algal species contain natural bioactive compounds that act as potent antimicrobial agents

Copyright: The authors. This article is an open access article licensed under the terms of the Creative Commons Attributin License (http:// creative commons.org/licenses/by/2.0) which permits unrestricted use, distribution and reproduction in any medium, provided the work is properly cited.
Spirulina, has some valuable antiviral and antioxidant compounds [12].

S. platensis used frequently as a dietary supplement had been found to exhibit many immune-stimulating and antiviral activities. It had been found to activate macrophages, NK cells, T-cells, B-cells, and to stimulate the production of interferon gamma and other cytokines. Natural substances isolated from S. platensis had been found to be potent inhibitors against several enveloped viruses by blocking viral absorption penetration and some replication stages of progeny viruses after penetration into cells [13].

Spirulina has been shown to have important antiviral activity, when administered at a low concentration it results in reduced viral replication whereas, at higher concentrations it blocks replication. A water soluble extract of Spirulina has been shown to inhibit viral cell-penetration and replication of the herpes simplex virus Type 1 (HSV-1) in cultured HeLa cells in a dose-dependent manner. The Spirulina extract inhibits viral protein synthesis without suppressing host cell functions. The antiviral activity is attributed to $\mathrm{Ca}-\mathrm{Sp}$, which has been shown to inhibit replication of many viruses by inhibition of viral penetration into target cells without host toxicity [14-17].

Foot and mouth disease (FMD) is a highly infectious disease of cattle, sheep, goats, pigs, and also 
wild animals. FMD virus (FMDV) is the etiological agent of disease that can affect cloven-hoofed livestock; it causes an acute disease characterized by fever, lameness and vesicular lesions on the feet, tongue snout, and teats, with a high morbidity and low mortality [18]. The causative FMDV is antigenically diverse having seven distinct serotypes and many variants within them. The virus exists as seven distinct serotypes. Vaccination or recovery from infection, with one serotype does not protect against infection from other serotypes [19].

The most effective FMD vaccines consisted of chemically inactivated FMDV and can only offer complete protection after 7 days of vaccination because of the time needed to trigger an immune response [20]. It has been proposed that a combination of vaccine and antiviral agents can be more efficacious strategy to treat FMD-infected animals; however, there are currently no approved anti-FMDV drugs for the treatment or prevention of FMDV [21]. There are several studies for testing the antiviral effect of synthetic compounds, and natural compounds were done against FMD [20,22-26].

This work was aimed to document the antiviral activates of $S$. platensis extract against FMDV different types to evaluate its replication in Baby Hamster Kidney (BHK) cell culture and in baby mice.

\section{Materials and Methods}

\section{Ethical approval}

Ethical approval was not necessary as animals were not used in the study at any stage.

\section{Algal source}

The algal materials were grown in the Phycology Unit, Botany Department, Faculty of Science, Tanta University, Egypt.

\section{Growth conditions}

The basal medium was adopted by Zarrouk [27], Raoof et al. [28]. The algal was cultivated on liquid Zarrouk medium. S. platensis was cultured in $3 \mathrm{~L}$ flasks containing $2 \mathrm{~L}$ Zarrouk medium (pH 9). The cultures were gassed with $0.3 \% \mathrm{CO}$ in air, and the algae were cultivated at $25 \pm 3^{\circ} \mathrm{C}$ for 15 days. The cultivated flasks were illuminated $24 \mathrm{~h}$ with continuous cool white fluorescent lamps at $400 \mathrm{~W}$ (equal $477 \mathrm{Lx}$ ).

\section{Growth measurements and harvesting}

The growth rate of $S$. platensis was monitoring every 3 days through cultivation period by determining the dry weight and optical density at $670 \mathrm{~nm}$ The cells were harvested at the stationary phase, by centrifugation at $10,000 \mathrm{~g}\left(4^{\circ} \mathrm{C}\right)$ for $15 \mathrm{~min}$, and the cells masses were stored at $-20^{\circ} \mathrm{C}$ until use [29].

\section{Extraction of S. platensis}

After collection, $S$. platensis samples were washed with freshwater several times to remove salts and debris and air dried. $500 \mathrm{~g}$ of the powdered samples were macerated and mixed with $2000 \mathrm{ml}$ of $95 \%$ ethanol until such time all materials were submerged and allowed to stand for $24 \mathrm{~h}$ with occasional shaking in a dark condition and After $24 \mathrm{~h}$, it was filtered. The crude residue was soaked again in a fresh $95 \%$ ethanol for another $48 \mathrm{~h}$. The filtrate from the first and second soaking was then mixed together. The combined filtrates were concentrated using rotary evaporator at $50^{\circ} \mathrm{C}$. The resulting concentrated extract was further concentrated by the use of a vacuum oven to remove residual solvent [30].

\section{Cell culture}

The most susceptible cells for FMDV multiplication were BHK cells (BHK 21 clone 13). These cells were supplied by the Animal Virus Institute, Pirbright, UK. They were propagated at FMD Department, Veterinary Serum and Vaccine Research Institute, Abbassia, Cairo using minimum essential medium with Earl's salts and 8-10\% sterile new born calf serum according to the technique described by Macpherson and Stocher [31].

\section{FMDV}

The used viruses in this study were the locally isolated FMDV types O/Panasia, A/Iran 05, and SAT2/2012 which were isolated during outbreaks in Egypt and confirmed by the World Reference Laboratory for FMD (WRL) Pirbright Institute, UK as $\mathrm{O} /$ Panasia, $\mathrm{A} / \mathrm{Iran}$ 05, and SAT2/2012.Viruses were used for the production of the trivalent FMD vaccine.

\section{Cytotoxicity test}

The cytotoxicity of $S$. platensis was evaluated according to Walum et al. [32], Simões et al. [33] in which the sample $(100 \mathrm{mg})$ was dissolved in $1 \mathrm{ml}$ of ethanol with adding $24 \mathrm{ul}$ of $\times 100$ of antibiotic then two-fold dilutions were done. $100 \mathrm{ul}$ of each dilution were inoculated in BHK cell line previously cultured in 96 well tissue cultures plates to estimate the nontoxic dose of the tested sample. The assay was done using cell morphology evaluation by inverted light microscope.

\section{Cell morphology evaluation by inverted light microscope}

After $24 \mathrm{~h}$ of incubation of BHK plates at $37^{\circ} \mathrm{C}$, Where the cell monolayers were confluent, the medium was removed from each well and replaced an equal volume of $(100 \mathrm{ul})$ growth media alone (cell controls) and with $100 \mathrm{ul}$ of two-fold dilution of tested sample. The plates were incubated at $37^{\circ} \mathrm{C}$ and examined 2 days after by inverted light microscope. Cell morphology was observed daily microscopically detectable morphological alternations, such as loss of confluence, cell rounding and shrinking, and cytoplasm granulation and vacuolization. Morphological changes were scored [33].

\section{Antiviral assays of S. platensis against FMDV Using BHK cells cultures}

It was done according to Boseila [25] and El-Baz et al. [34]. Briefly, non-toxic dilution of Spirulina extracts $(100 \mu \mathrm{l})$ was mixed with $100 \mu \mathrm{l}$ of each 
type of FMDV solution (A, O, SAT2). The mixture was incubated for $30 \mathrm{~min}$ at $37^{\circ} \mathrm{C}$, then 10 -fold dilutions from each mixture were done $(100 \mu l$ from the mixture add to $900 \mu \mathrm{l}$ media...i.e.) $50 \mu \mathrm{l}$ from each dilution inoculated in tissue culture plates BHK cells in 96 multi well-plates. The cultures were then incubated at $37^{\circ} \mathrm{C}$. After $24 \mathrm{~h}$, the plates were examined for viral cytopathic effect (CPE) under an inverted light microscope. The presence of $100 \% \mathrm{CPE}$ in virus infectivity considers control. FMDV titer for each type of FMDV was calculated to evaluate the antiviral activity of the Spirulina extract against FMDV different types.

\section{Unweaned baby mice}

According to [23-35] 2-3 day old baby Swiss mice were inoculated with $0.1 \mathrm{ml}$ intraperitonially from the mixture of FMDV different types $\left(10^{7} \mathrm{ID}_{50} / \mathrm{ml}\right)$ and different concentration of Spirulina extracts (six mice for each dilution). Besides that, a group of baby mice inoculated with FMDV only as a control. After $48 \mathrm{~h}$ post inoculation, all the baby mice examined to evaluate the antiviral action of Spirulina extract against FMDV three types.

Paralysis at hind limps of baby mice or death of infected mice means that these mice infected with FMDV death after $24 \mathrm{~h}$ is non-specific.

\section{Results}

These results showed that there was a direct relationship between increasing concentration of the Spirulina extract and the cytotoxicity of the treated cells, until reaching $50 \mu \mathrm{g} / \mathrm{ml}$, there was no cytotoxicity found in the treated cells. There was a clear reduction in the FMD virus titer of different strains was achieved by incubating the virus with non toxic dose of $S$. platensis extract at concentration of $(50 \mu \mathrm{g} / \mathrm{ml})$ compared with the non treated virus (virus control).

The result also showed the inhibitory concentration $50 \%\left(\mathrm{IC}_{50}\right)$ of $S$. platensis which give $50 \%$ mortality of infected baby mice with FMDV.

\section{Discussion}

The current situation in the use of antiviral drugs in veterinary medicine is characterized by a novel and optimistic approach. The use of antiviral drugs in livestock animals is investigated for the treatment or control of disease on a large scale (mass treatment), whereas in companion animals an individual approach is favored. The inactivated vaccines of FMDV are not complete success to control the disease [36]. Since the FMDV is RNA virus which it has continuous antigenic drift [37]. The virucidal drugs have been studied for decreasing the outbreaks, and to reduce the number of infected animals during outbreaks. This paper studies the antiviral activity of ethanol extract of $S$. platensis against FMDV types (A, O, SAT2). Prior to evaluating antiviral activates of $S$. platensis against FMDV the cytotoxicity of the extracts on the host cells (BHK cells) was studied. The natural extract ( $S$. platensis) should be active against the virus without inducing significant toxicity on the host cell. Therefore, the maximum concentration of the $S$. platensis at which there is no visible toxicity to the cell was determined. In the study of Kasetsart [38], the antiviral activity of 42-plant crude-extracts against the FMDV Type O on BHK cells was studied. The concentration of crude-extracts $(0.2 \mathrm{~g} / \mathrm{ml})$ was two-fold diluted with Dulbecco's modified Eagle's medium adding 5\% fetal bovine serum for cytotoxicity testing on BHK-21.

Regarding the results demonstrated in Table-1, it was showed clearly that the cytotoxicity of the BHK cells was directly proportional to the concentration of the Spirulina extract where increased concentration of the extract was accompanied by changes in cell morphology. At all concentration above $(100 \mu \mathrm{g} / \mathrm{ml})$ showed $100 \%$ toxicity, the cells became rounded and nuclei were more prominent, and the cells were found to float in the medium. $50 \%$ cytotoxicity appear at this concentration cells were found to be similar to apoptotic cells, However, at a concentration of $50 \mu \mathrm{g} / \mathrm{ml}$ the cells appear normal, and there was no cytotoxicity. These results agree with Abdo et al. [39] who recorded the non-toxic concentration of methanol and water extracts of $S$. platensis, Anabaena sphaerica, Chroococcus turgidus, Oscillatoria limnetica, and Cosmarium leaves in Hep-2 cell line was $2 \mathrm{mg} / \mathrm{ml}$ while in the study of El-Baz et al. [34]. They found that the non-toxic dose of Spirulina extract was ranged from 1.6 to $1.9 \mathrm{mg} / \mathrm{ml}$ which means no big difference between the different cell lines including buffalo green monkey kidney cells, Hep-2 derived from human, epidermoid larynx carcinoma, MA104, derived from embryonic rhesus monkey kidney tissue, and $\mathrm{CaCo}-2$ heterogeneous human.

Concerning the results in Table-2, it was noticed that the non-toxic dose of $S$. platensis $(50 \mu \mathrm{g} / \mathrm{ml})$ revealed $35 \%, 28.5 \%$, and $31 \%$ reduction in infectious titer of FMDV Types A, O, and SAT2, respectively. Where the mean of virus titer was $10^{7}$ tissue

Table-1: Cytotoxicity of S. platensis on BHK cells.

\begin{tabular}{lcc}
\hline $\begin{array}{l}\text { Dilution of } \\
\text { S. platensis } \\
\text { extract }\end{array}$ & $\begin{array}{l}\text { Concentration } \\
\text { of S. platensis }\end{array}$ & $\begin{array}{c}\text { Cytotoxicity } \\
\% \text { on BHK } \\
\text { cells }\end{array}$ \\
\hline $1 / 2$ & $50 \mathrm{mg}$ & 100 \\
$1 / 4$ & $25 \mathrm{mg}$ & 100 \\
$1 / 8$ & $12.5 \mathrm{mg}$ & 100 \\
$1 / 16$ & $6.25 \mathrm{mg}$ & 100 \\
$1 / 32$ & $3.13 \mathrm{mg}$ & 100 \\
$1 / 64$ & $1.6 \mathrm{mg}$ & 100 \\
$1 / 128$ & $0.8 \mathrm{mg}(800 \mathrm{ug})$ & 100 \\
$1 / 256$ & $0.4 \mathrm{mg}(400 \mathrm{ug})$ & 100 \\
$1 / 512$ & $0.2 \mathrm{mg}(200 \mathrm{ug})$ & 100 \\
$1 / 1024$ & $0.1 \mathrm{mg}(100 \mathrm{ug})$ & 50 \\
$1 / 2048$ & $0.05 \mathrm{mg}(50 \mathrm{ug})$ & 0 \\
\hline
\end{tabular}

BHK=Baby Hamster Kidney, S. platensis=Spirulina platensis 
Table-2: Antiviral effect of non-toxic dose of S. platensis on FMDV titers expressed as $\log _{10} \operatorname{TCID}_{50} / \mathrm{ml}$.

\begin{tabular}{|c|c|c|c|c|c|}
\hline $\begin{array}{l}\text { FMDV } \\
\text { strain }\end{array}$ & $\begin{array}{l}\text { Number of } \\
\text { virus samples }\end{array}$ & $\begin{array}{c}\text { Initial titer of tested } \\
\text { virus samples* }\end{array}$ & $\begin{array}{l}\text { Final titer of tested } \\
\text { virus samples* }\end{array}$ & $\begin{array}{l}\text { Mean of final titer of } \\
\text { tested virus samples }\end{array}$ & $\begin{array}{l}\text { Mean \% of } \\
\text { reduction** }\end{array}$ \\
\hline \multirow[t]{3}{*}{ O/Panasia } & $\mathrm{S} 1$ & 6 & 3.5 & 4.5 & 35.7 \\
\hline & S2 & 7 & 4 & & \\
\hline & S3 & 8 & 6 & & \\
\hline \multirow[t]{3}{*}{ A/Iran 05} & S4 & 6 & 3.5 & 5 & 28.5 \\
\hline & S5 & 7 & 5 & & \\
\hline & S6 & 8 & 6.5 & & \\
\hline \multirow[t]{3}{*}{ SAT2/2012 } & S7 & 6 & 4 & 4.8 & 31 \\
\hline & S8 & 7 & 4.5 & & \\
\hline & S9 & 8 & 6 & & \\
\hline Virus control & $\mathrm{S} 10$ & 7 & 7 & 7 & - \\
\hline
\end{tabular}

*Virus titer values are expressed as $\log _{10} \mathrm{TCID}_{50} / \mathrm{ml}$, **Percentage of reduction of virus titer. TCID=Tissue culture infectious dose, FMDV=Foot and mouth disease virus, S. platensis=Spirulina platensis

Table-3: The effect of different concentrations of S. platensis against different types of FMDV in baby mice.

\begin{tabular}{|c|c|c|c|c|c|c|c|}
\hline \multirow{3}{*}{$\begin{array}{l}\text { S. platensis } \\
\text { concentration }\end{array}$} & \multirow{3}{*}{$\begin{array}{c}\text { Number } \\
\text { of baby } \\
\text { mice }\end{array}$} & \multicolumn{6}{|c|}{ S. platensis concentration } \\
\hline & & \multicolumn{2}{|c|}{ FMDV Type (0) } & \multicolumn{2}{|c|}{ FMDV Type (A) } & \multicolumn{2}{|c|}{ FMDV Type (SAT2) } \\
\hline & & $\begin{array}{l}\text { Number of } \\
\text { dead mice }\end{array}$ & IC (\%) & $\begin{array}{l}\text { Number of } \\
\text { dead mice }\end{array}$ & IC (\%) & $\begin{array}{l}\text { Number of } \\
\text { dead mice }\end{array}$ & IC $(\%)$ \\
\hline $5 \mathrm{ug} / \mathrm{ml}$ & 6 & 6 & 0 & 6 & 0 & 6 & 0 \\
\hline $10 \mathrm{ug} / \mathrm{ml}$ & 6 & 4 & 33 & 6 & 0 & 5 & 17 \\
\hline $20 \mathrm{ug} / \mathrm{ml}$ & 6 & 3 & $50 *$ & 5 & 17 & 3 & 50 \\
\hline $50 \mathrm{ug} / \mathrm{ml}$ & 6 & 2 & 67 & 3 & 50 & 2 & 67 \\
\hline $100 \mathrm{ug} / \mathrm{ml}$ & 6 & 1 & 83 & 2 & 67 & 2 & 67 \\
\hline $200 \mathrm{ug} / \mathrm{ml}$ & 6 & 0 & 100 & 1 & 83 & 1 & 83 \\
\hline Virus control & 6 & 6 & 0 & 6 & 0 & 6 & 0 \\
\hline
\end{tabular}

*Give $50 \%$ mortality of infected baby mice. IC=Inhibitory concentration of S. platensis. FMDV=Foot and mouth disease virus, S. platensis $=$ Spirulina platensis

culture infectious dose (TCID) 50/ml before treatment the virus with Spirulina extract became $10^{4.5}, 10^{5}, 10^{4.8}$ TCID 50/ml for FMDV (O, A, and SAT2), respectively, after treatment our results come to agree with those obtained by Walum et al. [32] who recorded that $53.3 \%, 66.7 \%, 76.7 \%, 56.7 \%$, and $50 \%$ reductions in vitro for infectious units of adenovirus Type 7 , coxsackievirus B4, astrovirus Type 1 , rotavirus Wa strain, and adenovirus Type 40, respectively, treated with Spirulina extract also the result come to agree with Corona et al. [40] who mentioned that hot water extract of Spirulina maxima inhibited the infection for adenovirus Type 3 with a percentage $<20 \%$, with an $\mathrm{IC}_{50} 5.2 \mathrm{mg} / \mathrm{ml}$. The mode of action of $S$. platensis is inhibits viral protein synthesis without suppressing host cell functions.

On another hand the antiviral activity could be due to highly polar compounds present in ethanol extract of $S$. platensis in agreement with El-Baz et al. [34] and Abdo et al. [39] who explained the highly polar compounds in the methanol and ethanol extract of $S$. platensis on adenovirus Type 40, while Corona et al. [40] reported that Spirulina maxima methanol extract did not have a virucidal effect on herpes virus, inhabitation of herpes virus infection was explained by blocking the adsorption and penetration events of the $7^{\text {th }}$ viral replication cycle.

Regarded the result in Table-3, the inhibitory concentration of $S$. platensis $50 \%$ in baby mice was
$20 \mu \mathrm{g} / \mathrm{ml}$ for FMDV Types $\mathrm{O}$ and SAT2 and $50 \mathrm{ug} / \mathrm{ml}$ for Type A. This result come to agree with Richards et al. [35] who showed that the prophylactic administration of the marine algae extracts was effective in reducing final mortality or prolonging the mean day of death of inoculated mice by the intra peritoneal, intra cerebral, or intranasal routes with HSV-2, beside that Hayashi et al. [41] found that Spirulina enhances the immune response, particularly the primary response, by stimulating macrophage functions, phagocytosis, and interleukin-1 production in baby mice. Moreover, Neekhra et al. [42] concluded that $S$. platensis have potent antinociceptive and anxiolytic activity in Swiss albino mice.

\section{Conclusion}

This study confirmed the biological activity of the ethanol extract of $S$. platensis against FMDV Types O, A, and SAT2. From the results, S. platensis is could be useful as antiviral lead to limitation of infection among animals during outbreaks but further studies need to evaluate the $S$. platensis on experimental or naturally infected farm animals to establish the effective dose side affected period of treatment of $S$. platensis.

\section{Authors' Contributions}

HMD: Designed the study. HMD and EMS: Preparation and extraction to $S$. platensis, Preparation 
of BHK, determine the non toxic dose of $S$. platensis against BHK, study the effect of $S$. platensis as antivirus on FMD serotype O, A and SAT2 on BHK cell and on baby mice, drafted and revised the manuscript. Both authors read and approved the final manuscript.

\section{Acknowledgments}

The authors are thankful to Prof. Dr. Sayed Zeidan Director of VSVRI, and all members of FMD department. Furthermore, thanks to Prof. Dr. Mohamed Hassan Khoudier, and Prof. Dr. Khayrat Abdel Mageed Elian for reviewing this work. This work was funded by Veterinary Serum and Vaccine Research Institute, Abbasia, Cario, Egypt.

\section{Competing Interests} interest.

The authors declare that they have no competing

\section{References}

1. Febles, C.I., Arias, A. and Gill-Rodriguez, M.C. (1995) In vitro study of antimicrobial activity in algae (Chlorophyta, Phaeophyta and Rhodophyta) collected from coast of Tenerife (in Spanish). Anu. Estud. Canarios, 34: 181-192.

2. Ely, R., Supriya, T. and NaaiK, C.G. (2004) Antimicrobial activity of marine organisms collected of the coast of South East India. J. Exp. Bio. Ecol., 309: 121-127.

3. Kumar, V., Tirumalai, P.S., Singh, A., Bhatnagar, A.K. and Shrivastava, J.N. (2013) Natural compounds from algae and S. platensis \& its antimicrobial activity. Indo Glob. J. Pharm. Sci., 3(3): 212-223.

4. Fujisawa, T., Narikawa, R., Okamoto, S., Ehira, S., Oshimura, H., Suzuki, I., Masuda, T., Mochimaru, M., Takaichi, S., Awai, K., Sekine, M., Horikawa, H., Yashiro, I., Omata, S., Takarada, H., Katano, Y., Kosugi, H., Tanikawa, S., Ohmori, K., Sato, N., Ikeuchi, M., Fujita, N. and Ohmori, M. (2010) Genomic structure of an economically important cyanobacterium, Arthrospira (Spirulina) platensis NIES-39. DNA Res. Adv., 17(2):85-103.

5. Karali, F. Arthrospira platensis. Bio203 University of Wisconsin-La Crosse.

6. Moreira, L.M., Ribeiro, A.C., Duarte, F.A., Morais, M.G. and Soares, L.A.S. (2013) S. platensis biomass cultivated in Southern Brazil as a source of essential minerals and other nutrients. Afr. J. Food Sci., 7(12): 451-455.

7. Yaakob, Z., Ali, E., Zainal, A., Mohamad, M. and Takriff, M.S. (2014) An overview: Biomolecules from microalgae for animal feed and aquaculture. J. Biol. Res. Thessaloniki, 21: 6 .

8. Gheda, S.F., Khalil, M.A. and Gheida, S.F. (2013) In vitro and in vivo preliminary results on $S$. platensis for treatment of impetigo: Topical cream application. Afr. J. Biotechnol., 12(18): 2498-2509.

9. Hetta, M., Mahmoud, R., El-Senousy, W., Ibrahim, M., El-Taweel, G. and Ali, G. (2014) Antiviral and antimicrobial activities of S. platensis. World J. Pharm. Pharm. Sci., 3(6): 31-39.

10. Whitton, B.A., Potts, M., editors. (2000) The Ecology of Cyanobacteria in the Netherlands. Kluwer Academic Publishers, Dordrecht, Netherlands.

11. Mendes, R.F., Nobre, B.P., Cardoso, M.T., Peveira, A. and Palavra, A.F. (2003) Supercritical carbon dioxide extraction of compounds with pharmaceutical importance from microalgae. Inorg. Chim. Acta, 356: 328-334.

12. Ozdemir, G., Karabay, N.U., Dalay, C.M. and Pazarbasi, B. (2004) Antibacterial activity of volatile component and various extracts of S. platensis. Phytother. Res., 18: 754-757.

13. Yakoot, M. and Salem, A. (2012) S. platensis versus silymarin in thetreatment of chronic hepatitis $\mathrm{C}$ virus infection a pilot randomized, comparative clinical trial. $B M C$ Gastroenterol., 12: 32.

14. Kulshreshtha, A., Zacharia, A.J., Jarouliya, U., Bhadauriya, P., Prasad, G.B. and Bisen, P.S. (1995) Spirulina in health care management. Curr. Pharm. Biotechnol., 9: 400-405.

15. Lee, E.H., Park, J.E., Choi, Y.J., Huh, K.B. and Kim, W.Y. (2008) A randomized study to establish the effects of Spirulina in type 2 diabetes mellitus patients. Nutr. Res. Pract., 2(4): 295-300.

16. Deng, R. and Chow, T.J. (2010) Hypolipidemic, antioxidant, and antiinflammatory activities of microalgae Spirulina. Cardiovasc. Ther., 28(4): e33-45.

17. Karkos, P.D., Leong, S.C., Karkos, C.D., Sivaji, N. and Assimakopoulos, D.A.P. (2011) Spirulina in clinical practice: Evidence-based human applications. Evid. Based Complement. Alternat. Med., 2011: 531053.

18. Depa, P.M., Dimri, U., Sharma, M.C. and Tiwari, R. (2012) Update on epidemiology and control of foot and mouth disease - A menace to international trade and global animal enterprise. Vet. World, 5(11): 694-704.

19. Grubman, M.J. (2005) Development of novel strategies to control foot-and-mouth disease marker vaccines and antivirals. Biologicals, 33: 227-234.

20. Deshpande, T.M. and Chaphalkar, S.R. (2013) Antiviral activity of plant extracts against FMDV in vitro a preliminary report. Int. J. Inst. Pharm. Life Sci., 3(4): 1-18.

21. Vagnozzi, A., Stein, D.A., Iversen, P.L. and Elizabeth, R. (2007) Inhibition of foot-and mouth disease virus infections in cell cultures with antisensemorphino oligomers. J. Virol., 81(21): 11669-11680.

22. Wachsman, M.B., Castilla, V. and Coto, C.E. (1998) Inhibition of foot and mouth disease virus (FMDV) uncoating by a plant-derived peptide isolated from Melia azedarach L leaves. Arch. Virol., 143(3): 581-90.

23. Saad, M.A.A. and Fawzy, H.G.I.V. Antiviral action of ribavirin on FOOT and mouth disease virus replication in cell culture and laboratory animals. $7^{\text {th }}$ Veterinary Medicine- Zagazig Conference (21-23 July, 2004), Sharm EL-Sheikh.

24. Chungsamarnyart, N., Sirinarumitr, T., Chumsing, W. and Wajjawalku, W. (2007) In vitro study of antiviral activity of plant crude-extracts against the foot and mouth disease virus. Kasetsart. J., 41: 97-103.

25. Boseila, A.A.H. (2011) Preliminary in vitro study for using aqueous cinnamon extract against foot-and-mouth disease virus. New York Sci. J., 4(11): 59-63.

26. Boseila, A.A.H. and Hatab, E.M.A. (2011) Evaluation of the antiviral activity of sage leaves (Salvia officinalis) extract against foot-and-mouth disease virus. Agricultural Relations (FAR), Egypt, 3-5 October. p301-308.

27. Zarrouk, C. (1966) Contribution a 1, etuded, unecyanophycee. Influence de divers facteurs physiques et chimiquessularcroissance et laphotosynthese de Spirulina maxima. $\mathrm{Ph}$. D. Thesis, Universite de Paris, Paris.

28. Raoof, B., Kaushik, B.D. and Prasanna, R. (2006) Formulation of a low-cost medium for mass production of Spirulina. Biomass. Bioenergy, 30: 537-542.

29. Abd, E., Baky, H., Hanaa, E., Baz, K.F. and EL-Latife, S.A. (2013) Induction of sulfated polysaccharides in $S$. platensisas response to nitrogen concentration and its biological evaluation. J. Aquac. Res. Dev., 5: 1.

30. Fayzunnessa, N., Morshed, A., Uddin, A., Parvin, A. and Saifur, R. (2011) In vivo study on the efficacy of hypoglycemic activity of Spirulina plantesis in long evan rats. Int. J. Biomol. Biomed., 1: 27-33.

31. Macpherson, I. and Stocher, M. (1962) Polyma transformation hamster cell clones, an investigation of gebetic factors affecting cell competence. Virology, 16: 147-151.

32. Walum, E., Strenberg, K. and Jenssen, D. (1990) Understanding Cell Toxicology: Principles and Pratice. 
Ellis Howood, New York. p97-1119.

33. Simões, C.M.O., Amoros, M. and Girre, L. (1999) Mechanism of antiviral activity of triter penoid saponins. Phytother. Res., 21: 317-325.

34. El-Baz, F.K., El-Senousy, W.M., El-Sayed, A.B., Kamel, M.M. (2013) In vitro antiviral and antimicrobial activities of S. platensis. J. Appl. Pharm. Sci., 3(12): 052-056.

35. Richards, J.T., Kern, E.R., Glasgow, L.A., Overall, Jr., J.C., Frank Deign, E. and Hatch, M.T. (1978) Antiviral activity of extracts from marine algae. Antimicrob. Agents Chemother. 14(1): 24-30.

36. Barteling, S. and Vreeswijk, J. (1991) Development in footand-mouth disease vaccines. Vaccine, 9: 75-88.

37. Belsham, G.J. (1993) Distinctive features of foot and-mouth disease virus, a member of the picorna virus family; aspects of virus protein synthesis, protein processing and structure.
Prog. Biophys. Mol. Biol., 60: 241-260.

38. Kasetsart, J. (2007) In vitro study of antiviral activity of plant crude-extracts against the foot and mouth disease virus. Nat. Sci., 41: 97-103.

39. Abdo, S.M., Hetta, M.H., El-Senousy, W.M., Salah El Din, R.A. and Ali, G.H. (2012) Antiviral activity of freshwater algae. J. Appl. Pharm. Sci., 2: 21-25.

40. Corona, A.H., Nieves, I., Meckes, M., Chamorro, M. and Barron, B.L. (2002) Antiviral activity of Spirulina maxima against herpes simplex virus type 2. Antiviral Res., 56: $279-285$.

41. Hayashi, O., Katoh, T. and Okuwaki, Y.(1994) Enhancement of antibody production in mice by dietary $S$. platensis. J. Nutr. Sci. Vitaminol., 40(5): 431-441.

42. Neekhra, S., Saraogi, R., Thakur, D. and Singh, N. (2014) Neurobiological activity of $S$. platensis in mice. J. Med. Chem. Drug Discov., 5: 21-32.

$* * * * * * * *$ 